\title{
Effect of chloride content in water on heart rate in narrow-clawed crayfish (Astacus leptodactylus)
}

\author{
P. Kozák ${ }^{(1)}$, T. Policar ${ }^{(1)}$, V.P. Fedotov(2) ${ }^{(2)}$ T.V. Kuznetsova( ${ }^{(2)}$, M. Buřič ${ }^{(1)}$, \\ S.V. Kholodkevich ${ }^{(2)}$
}

Received September 25, 2009 / Reçu le 25 septembre 2009

Revised December 7, 2009 / Révisé le 7 décembre 2009

Accepted December 11, 2009 / Accepté le 11 décembre 2009

Key-words: cardiac activity,

Astacus leptodactylus, crayfish, heart rate, chloride

\section{ABSTRACT}

A non-invasive method of recording cardiac activity was used to examine the impact of chloride level in water on narrow-clawed crayfish. This method permits one to record heart rate without any harm to the animal, and also locates changes in the shape and amplitude parameters of the response, which characterized the crayfish functional state. Altogether, eight levels of chloride $(100,400,800,1600,3200,6400,12800$ and $25600 \mathrm{mg} \cdot \mathrm{L}^{-1} \mathrm{NaCl}$ ) were evaluated. Already at low levels some crayfish were influenced. A clear reaction was evident starting from $3200 \mathrm{mg} \cdot \mathrm{L}^{-1}$ $\mathrm{NaCl}$. On the contrary, crayfish showed a high tolerance to high chloride levels, and the heart rate and stress index returned to normal within a few minutes or hours after $\mathrm{NaCl}$ addition.

\section{RÉSUMÉ}

Effet de la concentration de l'eau en chlorure sur la fréquence cardiaque chez l'écrevisse à pattes grêles (Astacus leptodactylus)

\begin{abstract}
Mots-clés : activité cardiaque, Astacus leptodactylus, écrevisse, fréquence cardiaque, chlorure

Une méthode non-invasive d'enregistrement de l'activité cardiaque a été utilisée pour étudier l'impact de la concentration de l'eau en chlorure chez l'écrevisse à pattes grêles. Cette méthode permet l'enregistrement du rythme cardiaque sans dommage pour l'animal et détermine également les changements dans la forme et l'amplitude des paramètres de la réponse, qui caractérise l'état fonctionnel de l'écrevisse. Au total, huit concentrations de chlorure (100, 400, 800, 1600, 3200, 6400,12800 et $25600 \mathrm{mg} \cdot \mathrm{L}^{-1} \mathrm{NaCl}$ ) ont été testées. Quelques écrevisses sont influencées dès les basses concentrations. Une réaction claire a bien été mise en évidence à partir de $3200 \mathrm{mg} \cdot \mathrm{L}^{-1} \mathrm{NaCl}$. Par contre, l'écrevisse montre une forte tolérance aux concentrations élevées de chlorure et la fréquence cardiaque et l'indice de stress reviennent à la normale en quelques minutes ou heures après l'addition de $\mathrm{NaCl}$.
\end{abstract}

\section{INTRODUCTION}

The morphology and physiology of the crustacean cardiovascular system have long been regarded as poorly organized and loosely controlled, and serving only as a conduit to carry

(1) University of South Bohemia in České Budějovice, Faculty of Fisheries and Protection of Waters, Zátiši 728/II, 38925 Vodňany, Czech Republic, kozak@vurh.jcu.cz

(2) St. Petersburg Scientific Research Centre for Ecological Safety, Laboratory of Experimental Ecology of Aquatic Systems, Korpusnaja str., 18, Saint-Petersburg 197110, Russia 
hemolymph. This view was based on early comparisons between the closed and open cardiovascular systems found in vertebrates and crustaceans, respectively. Further studies of the cardiovascular systems of decapod Crustaceana, however, have revealed a system that is more complex than previously thought. Hormonal and neural regulation of cardiac contractility, cardiac contraction frequency and cardioarterial valve tonus via the cardiac ganglion and pericardial organ have been demonstrated, e.g. in the crab Cancer magister (Airries and McMahon, 1992). Furthermore, cardiovascular responses towards environmental pertubations have also been identified (e.g. Airries and McMahon, 1994; Reiber et al., 1997; Reiber and McMahon, 1998).

Despite being freshwater animals, crayfish can also live in environments subject to variation in salinity. They are adaptable animals, tolerating a wide range of environmental variables (McMahon, 1986). For example, Cherkasina (1975) reported that Astacus leptodactylus survives in waters with salinity levels of 14 in the Caspian Sea and feeds on a variety of brackishwater organisms. Köksal (1988) found A. leptodactylus on the Baltic coast, and in the Black and Caspian Seas. Holdich et al. (1997) reported that Austropotabomius pallipes, A. leptodactylus and Pacifastacus leniusculus were capable of hyper-regulating their hemolymph osmotic pressure up to approximately $50 \%$ seawater, and hyporegulate at higher salinities. Some evidence was presented that crayfish growth might be improved by low salinities, possibly because less energy is being used for osmoregulatory purposes (Newsom and Davis, 1994). Rouse and Kartamulia (1992a, 1992b) reported that $100 \mathrm{mg} \cdot \mathrm{L}^{-1} \mathrm{NaCl}$ had a positive effect on acclimatization, molting success and survival of Cherax tenuimanus. Higher chloride concentrations also have favorable effects on the toleration of aquatic organisms to nitrate. The mechanism is well described (e.g. Morris, 2001; Kirschner, 2004). Positive effects of chloride aiding tolerance to nitrites have been demonstrated in fish (Hilmy et al., 1987; Atwood et al., 2001; Huertas et al., 2002; Fuller et al., 2003; Tavares and Boyd, 2003) and crayfish (Beitenger and Huey, 1981; Jeberg and Jensen, 1994). Crawford and Allen (1977) showed that toxicity of nitrite depended on water salinity. For example, the value of $96 \mathrm{hLC} 50$ increased from $5 \mathrm{mg} \cdot \mathrm{L}^{-1}$ of nitrites in tap water to $97 \mathrm{mg}$ at a level of $400 \mathrm{mg} \cdot \mathrm{L}^{-1} \mathrm{Cl}^{-}$for Orconectes limosus (Kozák et al., 2005).

On the contrary, crayfish could serve as good bioindicators, with quick reactions to several chemical changes and stimuli (Kholodkevich et al., 2008). Evaluation of the physiological state involves measurements of heart rate and cardiac activity patterns as key indicators of the conditions of the patient, and are included in all general clinical assessments in medical science (Swash and Mason, 1984). Numerous authors have found heart rate to be a useful indicator of changes in physiological state, even in crustaceans, molluscs and fish (e.g. Depledge and Andersen, 1990; Kholodkevich et al., 2008).

In this study we use a non-invasive method to evaluate the impact of chloride level in water on cardiac activity, as an indicator of physiological stage, in narrow-clawed crayfish.

\section{MATERIAL AND METHODS}

The experiment was conducted in the Laboratory of Experimental Ecology of Aquatic Systems, Saint-Petersburg Scientific Research Center for Ecological Safety (SRCES RAS) during September 2006.

\section{$>$ EQUIPMENT}

An original fiber-optic method for recording cardiac activity of Crustacean (Decapoda) and Mollusca (Fedotov et al., 2000; Kholodkevich et al., 2008) was used to measure the impact of chlorides on crayfish cardiac activity. A block-scheme of cardiac activity registration, signal transformation and automatic data processing in real time is depicted in Figure 1.

The infra-red light beam initially formed in the laser fiber-optic photoplethysmograph (LFOP) is transmitted to the animal by a thin optical fiber with a small sensor (weight less than $2 \mathrm{~g}$ ) 


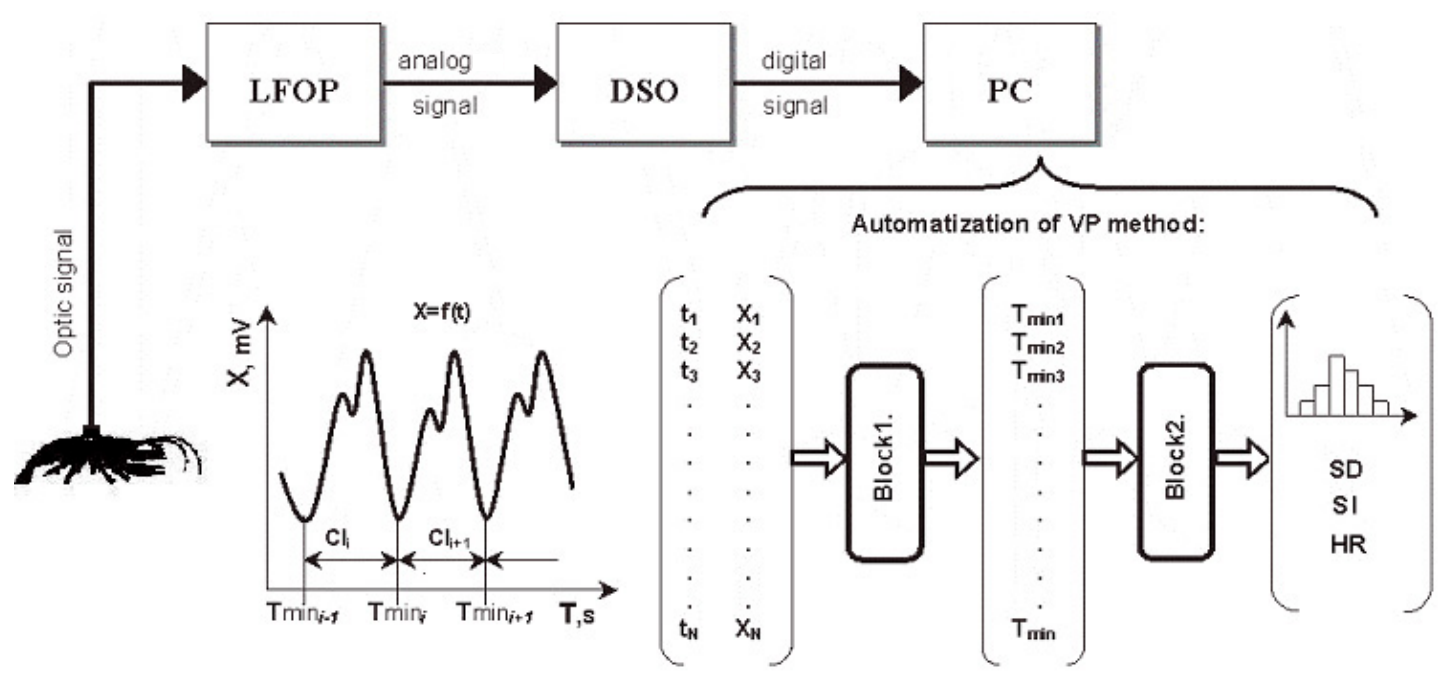

\section{Figure 1}

Block-scheme of cardiac activity registration, signal transformation and automatic data processing in real time. LFOP: laser fiber-optic photoplethysmograph, DSO: digital storing oscilloscope, PC: personal computer, SD: standard deviation, HR: heart rate, SI: stress index.

\section{Figure 1}

Schéma du système d'enregistrement de l'activité cardiaque, de transformation du signal et de traitement en temps réel des données. LFOP : photoplethysmographe à fibre optique-laser, DSO : oscilloscope digital de stockage, PC : ordinateur, SD : déviation standard, HR : fréquence cardiaque, SI : indice de stress.

attached to the carapace, thus illuminating the heart area with a scattered light. The optical signal modulated by the heart of the animal contains information on cardiac activity. After appropriate amplification and filtration in the LFOP, the analog signal is then transmitted to the digital storing oscilloscope (DSO), where it is converted into digital form by a 14-bit 16-channel analog-digital converter (ADC). Thereafter it is send to a personal computer (PC) via a USB port. The results create a photoplethysmogram, which can be further analyzed by various mathematical and statistical methods. An original software program, VarPulse ${ }^{\circledR}$, automatically reads data from the $A D C$, determines the duration of each cardiac interval in real time (block 1), and calculates a set of heart rhythm variability characteristics. The variation pulsometry (VP) method was used to study the distribution of cardiac intervals, and analyzed relationships between its shape and the functioning of the cardiac system (Figure 2). For this method the following characteristics were chosen as biomarkers: heart rate (HR) and the stress index (SI), which is defined by the formula (Kholodkevich et al., 2007, 2008):

$$
\mathrm{SI}=1 /\left(2 * \mathrm{Cl}_{\mathrm{m}} * \mathrm{SD}^{2}\right),
$$

where $\mathrm{Cl}_{\mathrm{m}}=$ means cardiac interval, which is related to $\mathrm{HR}$, with $\mathrm{HR}=60 / \mathrm{Cl}_{\mathrm{m}} ; \mathrm{SD}=$ standard deviation of heart rate.

\section{>ANIMALS AND EXPERIMENTAL CONDITIONS}

Sixteen narrow-clawed crayfish, originating from Sevan lake (Armenia), were used in the experiment. The animals were acclimatized for three weeks before the experiment to the controlled conditions. They were kept in two troughs $(2.5 \times 0.5 \times 0.3 \mathrm{~m})$ with shelters in a recirculating system. During the experiment, each crayfish was maintained in a separate 5 -liter aquarium with a shelter, which allowed the crayfish (with sensor and fiber attached) to stay inside (Figure 3). The total radius of the animal's migration $(25 \mathrm{~cm})$ was restricted 
P. Kozák et al.: Knowl. Managt. Aquatic Ecosyst. (2009) 394-395, 08

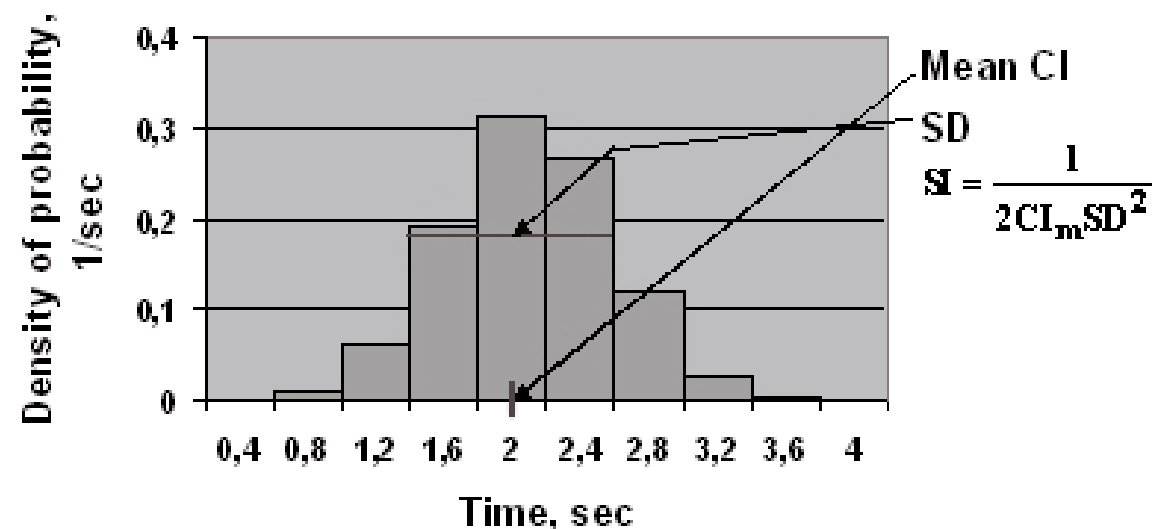

\section{Figure 2}

Variation pulsometry method to study relations between cardiac system functioning and the cardiac interval distribution law.

\section{Figure 2}

Méthode d'étude des relations entre le fonctionnement du cœur et la distribution des intervalles de pulsation.

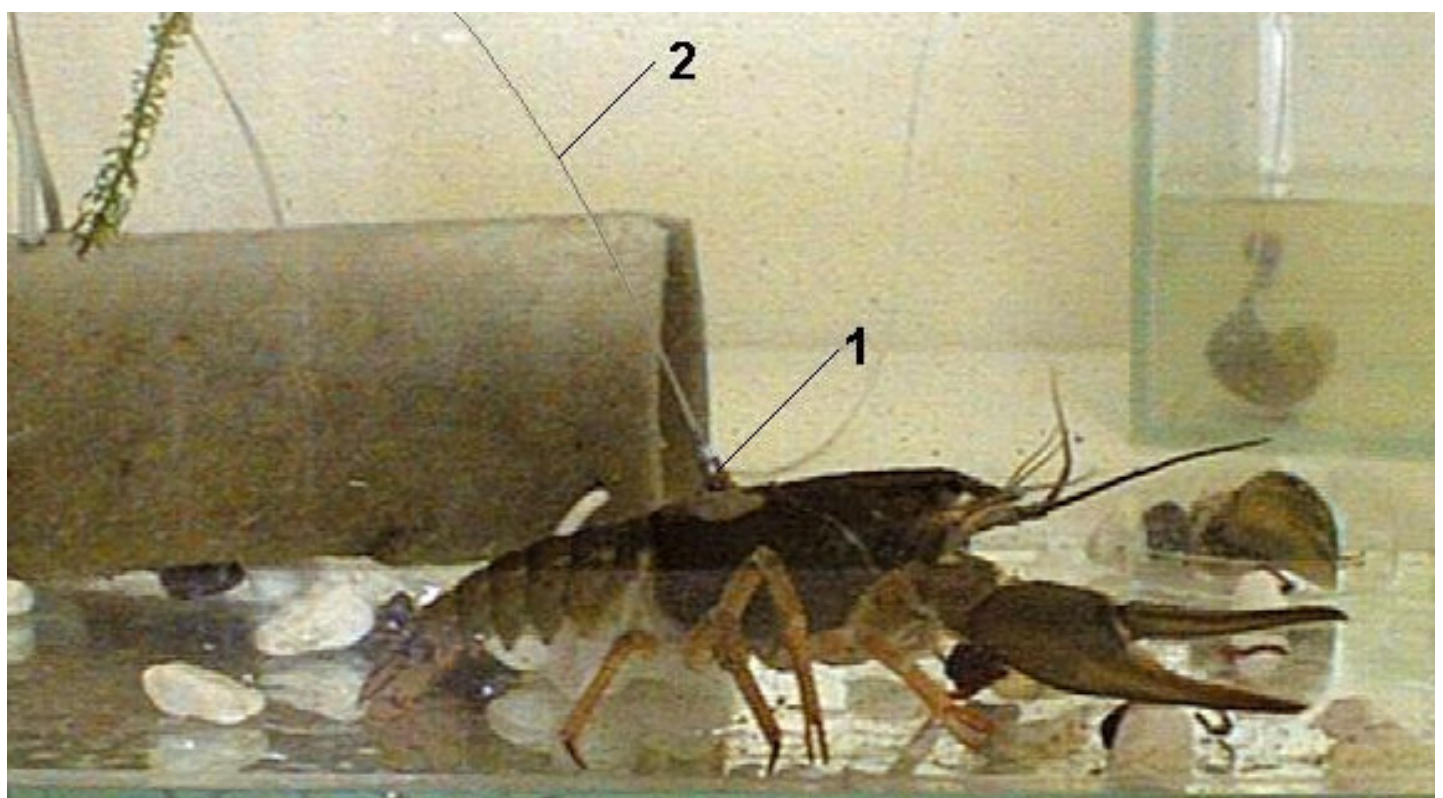

\section{Figure 3}

Narrow-clawed crayfish (Astacus leptodactylus) in 5-liter aquarium with a shelter, which allowed the crayfish with a sensor (1) and fiber (2) attached to stay inside.

Figure 3

Écrevisse à pattes grêles (Astacus leptodactylus) dans un aquarium de $5 \mathrm{~L}$ avec un abri, où l'écrevisse avec détecteur (1) et fibre (2) peut s'abriter. 
only by the size of the aquarium. The water level was set at $15 \mathrm{~cm}$. Crayfish were not fed during the experiment, and each animal was used only once. Water quality parameters were as follows: temperature $22{ }^{\circ} \mathrm{C}$, oxygen content $80-100 \%$ sat, $\mathrm{pH} 7.5, \mathrm{HCO}_{3}^{-} 32.5 \mathrm{mg} \cdot \mathrm{L}^{-1}$, $\mathrm{SO}_{4}^{2-} 19.3 \mathrm{mg} \cdot \mathrm{L}^{-1}, \mathrm{Cl}^{-} 7.8 \mathrm{mg} \cdot \mathrm{L}^{-1}, \mathrm{Ca}^{2+} 11.3 \mathrm{mg} \cdot \mathrm{L}^{-1}, \mathrm{Mg}^{2+} 2.9 \mathrm{mg} \cdot \mathrm{L}^{-1}, \mathrm{Na}^{2+} 3.3 \mathrm{mg} \cdot \mathrm{L}^{-1}, \mathrm{~K}^{+}$ $1.5 \mathrm{mg} \cdot \mathrm{L}^{-1}$. The experiment was performed in the daylight period in September ( $\mathrm{D}: \mathrm{N}=14: 10$ ).

\section{> EXPERIMENTAL DESIGN}

We tested the following eight levels of chloride content: 100, 400, 800, 1600, 3200, 6400, 12800 and $25600 \mathrm{mg} \cdot \mathrm{L}^{-1} \mathrm{NaCl}$. Each level was evaluated in two replicates. Animals were stocked in the evening of the day before the experiment to acclimatize to the new conditions. The relevant amounts of $\mathrm{NaCl}$, dissolved in $100 \mathrm{~mL}$ of water, were introduced to aquariums the following day when crayfish were in a tranquil stage (after stabilizing of heart rate and stress index for at least one hour). Crayfish were exposed to chloride for $24 \mathrm{~h}$.

\section{$>$ DATA ANALYSIS}

The non-parametric one-tailed Wilcoxon test was used to compare HR and SI before and after stimulation, with the level of significance at which the null hypothesis was rejected at $\alpha=0.05$. Data are presented as means $\pm 95 \%$ confidence intervals.

\section{RESULTS}

Some crayfish already showed a reaction at the lowest application levels of chloride. One crayfish had a slightly increased heart rate, but it was not reflected by the stress index. A clear stress index reaction just after $\mathrm{NaCl}$ addition was characterized by an increase during the first $20 \mathrm{~min}$ in both crayfish subjected to $400 \mathrm{mg} \mathrm{NaCl}$. However, only in one of them was a significant difference in heart rate confirmed (Table 1; Figure 4). The stress index decreased after $20 \mathrm{~min}$, and the heart rate stabilized to normal.

Interestingly, both heart rate and the stress index increased only slightly immediately after stimulation at 800 and $1600 \mathrm{mg} \mathrm{NaCl}$, but increased rapidly after the following $40 \mathrm{~min}$. A very clear reaction in heart rate and the stress index was evident from the level up to $1600 \mathrm{mg} \cdot \mathrm{L}^{-1}$ $\mathrm{NaCl}$ (Figure 5). Reactions were rapid and clear for both heart rate and the stress index.

On the contrary, crayfish showed a high tolerance to high chloride content in water, and heart rate and the stress index returned to normal within a few minutes or hours after $\mathrm{NaCl}$ addition, depending on the dosage of $\mathrm{NaCl}$. Only at the highest concentrations (12800 and $25600 \mathrm{mg} \mathrm{Cl}^{-} \cdot \mathrm{L}^{-1}$ ) did heart rate stabilize for a longer time.

\section{DISCUSSION}

In addition to a high sensitivity to changes in water quality, narrow-clawed crayfish showed a relatively high tolerance to water salinity. The highest concentration of chloride (25600 $\mathrm{mg} \mathrm{Cl}^{-} \cdot \mathrm{L}^{-1}=42 \mathrm{~g} \mathrm{NaCl}$ ) corresponds to its content in seawater $\left(35 \mathrm{~g} \cdot \mathrm{L}^{-1}\right)$. With concentrations inside ranges for brackish water $\left(0.6-10 \mathrm{~g} \cdot \mathrm{L}^{-1}\right)$, heart rate and the stress index returned to normal within one hour. These results confirmed the high tolerance and adaptability of narrow-clawed crayfish to high salinities reported by Cherkasina (1975) and Köksal (1988). However, at higher concentrations (up to $12800 \mathrm{mg} \mathrm{Cl} \cdot \mathrm{L}^{-1}$, which corresponds to $21 \mathrm{~g}$ of $\mathrm{NaCl}$ ), recovery of crayfish was delayed. Normally, freshwater fish and crustaceans are hyperosmotic to their environment. This phenomenon could be related to the capability of crayfish to hyper-regulate their osmotic pressure up to approximately $50 \%$ of seawater, and hyporegulation at higher salinities, as reported by Holdich et al. (1997). 

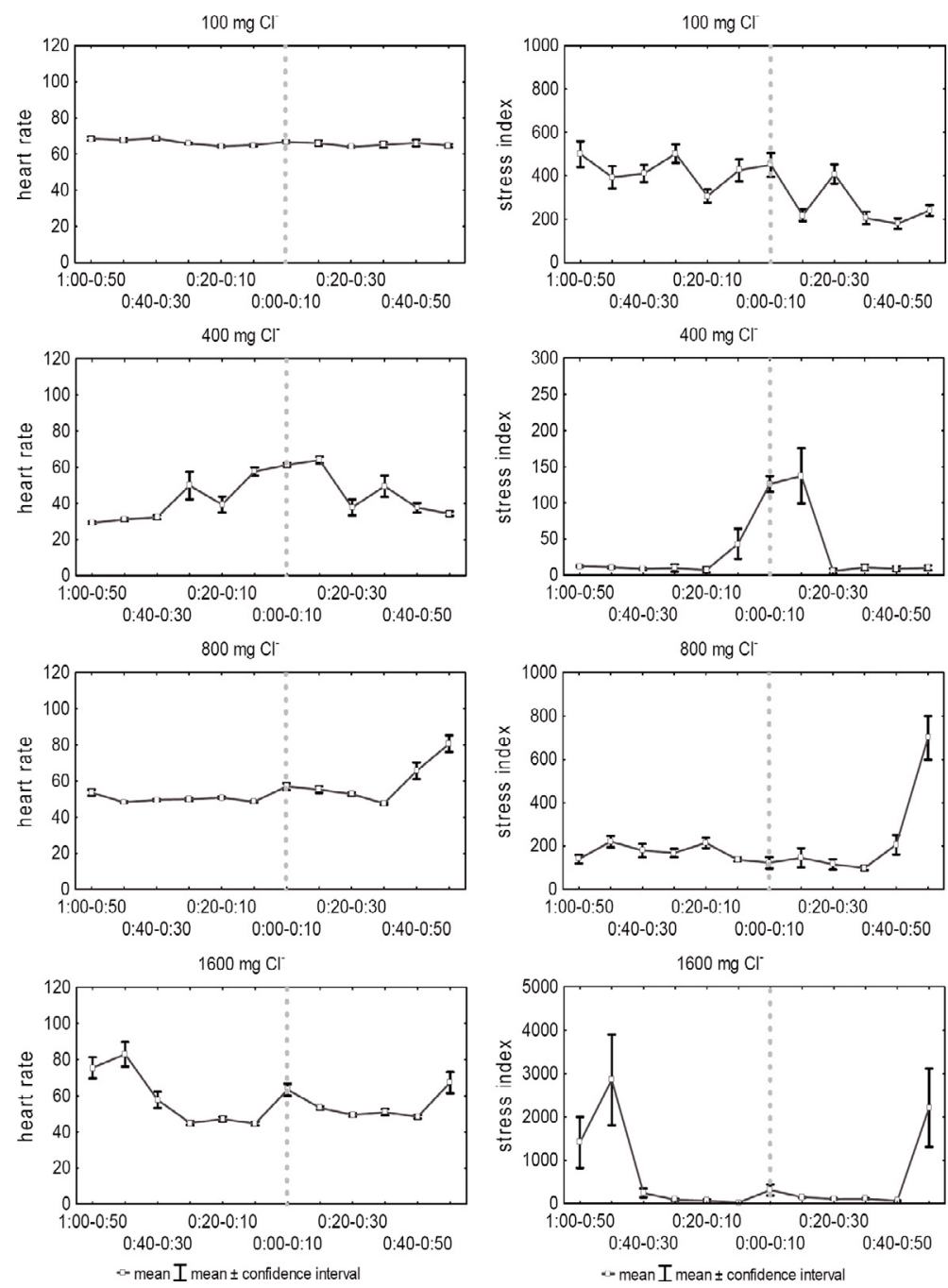

\section{Figure 4}

The course of heart rate and stress index of individual narrow-clawed crayfish (Astacus leptodactylus) one hour before and after stimulation (x-axis in minutes), respectively, at different chloride concentrations. The addition of salt into the water is marked as the time of 0:00.

\section{Figure 4}

Suivi de la fréquence cardiaque et de l'indice de stress d'individus de l'écrevisse à pattes grêles (Astacus leptodactylus) une heure avant et après la stimulation (axe des $x$ en minutes) à différentes concentrations en chlorure. L'ajout de sel à l'eau est fait au temps 0:00.

The high tolerance of crayfish to chloride is highly applicable in aquaculture, especially with the use of recirculation systems subject to a risk of high concentrations of nitrate. Fish and crayfish actively take in ions via the gills to counteract their loss through urine and passive outflow. Nitrite has an affinity for the active chloride uptake mechanism by chloride cells in the gills (Maetz, 1971). Chloride cells excrete ammonia or $\mathrm{H}^{+}$ions in exchange for $\mathrm{Na}^{+}$ions, and bicarbonate $\left(\mathrm{HCO}_{3}^{-}\right)$for $\mathrm{Cl}^{-}$ions (Love, 1980). $\mathrm{NO}_{2}^{-}$has affinity to $\mathrm{Cl}^{-} / \mathrm{HCO}_{3}^{-}$exchanging. A part of the $\mathrm{Cl}^{-}$demand is replaced by $\mathrm{NO}_{2}^{-}$when present in water. Fish with a higher rate of chloride uptake by gills (rainbow trout, perch, pike) are more sensitive to nitrites compared to species with a lower rate of chloride uptake (eel, common carp, tench) (Williams and Eddy, 1986). The competition between chloride and nitrite ion transport across the gill membrane explains that the higher concentration of $\mathrm{Cl}^{-}$protects animals against the toxic impact of nitrite (Jensen, 2003). In seawater a fifty- to hundredfold lower mortality was observed than 

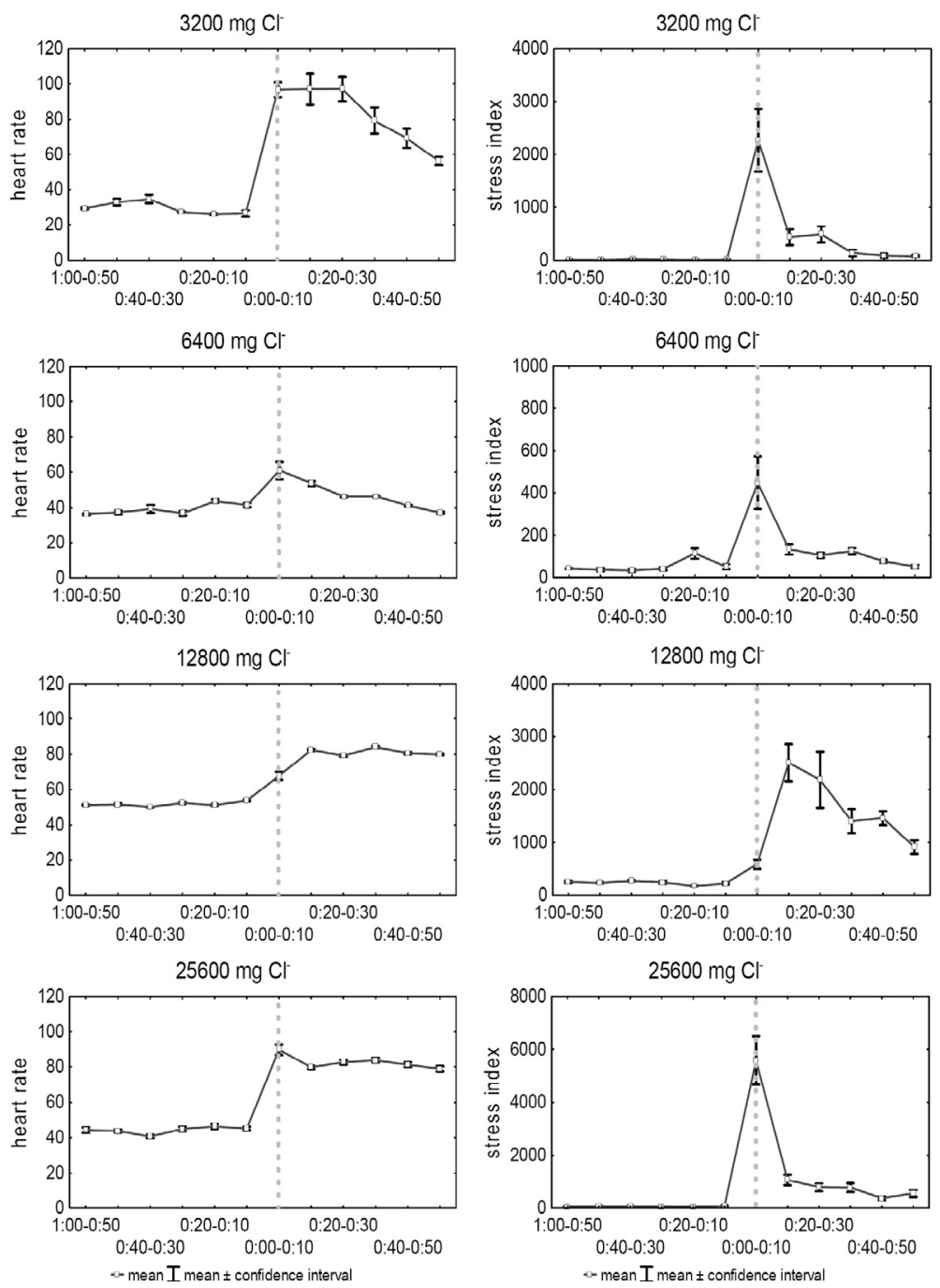

\section{Figure 5}

The course of heart rate and stress index of individual narrow-clawed crayfish (Astacus leptodactylus) one hour before and after stimulation (x-axis in minutes), respectively, at different chloride concentrations. The addition of salt into the water is marked as the time of 0:00.

\section{Figure 5}

Suivi de la fréquence cardiaque et de l'indice de stress d'individus de l'écrevisse à pattes grêles (Astacus leptodactylus) une heure avant et après la stimulation (axe des $x$ en minutes) à différentes concentrations en chlorure. L'ajout de sel à l'eau est fait au temps 0:00.

in fresh water at the same concentration of nitrite. The relationship between nitrite toxicity and chloride concentration is linear (Russo and Thurston, 1977; Kozák et al., 2005).

In conclusion, this study confirmed the high tolerance of narrow-clawed crayfish to high salinity, which is important both from an ecological and aquaculture point of view. Secondly, we proved that crayfish could be a good bioindicator, which could be used together with suitable analyzing equipment to monitor water quality, e.g. by industrial water companies.

\section{ACKNOWLEDGEMENTS}

This investigation was financially supported by the Czech Ministry of Education (projects USB RIFCH No. MSM6007665809 and ME 855) and the Ministry of Agriculture (project QH71305). 


\section{REFERENCES}

Airries C.N. and McMahon B.R., 1992. Aminergic modulation of circulatory performance in the crab, Cancer magister. Comparative Physiology, 11, 123-131.

Airries C.N. and McMahon B.R., 1994. Cardiovascular adaptations enhance tolerance of environmental hypoxia in the crab Cancer magister. J. Exp. Biol., 190, 23-41.

Atwood H.L., Fontenot Q.C., Tomasso J.R. and Isely J.J., 2001. Toxicity of nitrite to Nile tilapia: Effect of fish size and environmental chloride. N. Am. J. Aquacult., 63, 1, 49-51.

Beitinger T.L. and Huey D.W., 1981. Acute toxicity of nitrite to crayfish Procambarus simulans in varied environmental conditions. Environ. Pollut., ser. A, 29, 4, 305-311.

Cherkasina N.Ya., 1975. Distribution and biology of crayfishes of genus Astacus (Crustacea, Decapoda, Astacidae) in the Turkmen waters of the Caspian Sea. Freshwater Crayfish, 2, 553-555.

Crawford R.E. and Allen G.H., 1977. Seawater inhibition of nitrite toxicity to Chinook salmon. Trans. Am. Fish. Soc., 106, 105-109.

Depledge M.H. and Andersen B.B., 1990. A computer-aided physiological monitoring system for continuous, long-term recording of cardiac activity in selected invertebrates. Comp. Biochem. Physiol., $96 A, 4,473-477$.

Fedotov V.P., Kholodkevich S.V. and Strochilo A.G., 2000. Study of contractile activity of the crayfish heart with the aid of a new non-invasive technique. J. Evol. Biochem. Physiol., 96A, 4, 473-477.

Fuller S.A., Henne J.P., Carmichael G.J. and Tomasso J.R., 2003. Toxicity of ammonia and nitrite to the Gila trout. N. Am. J. Aquacult., 65, 2, 162-164.

Hilmy A.M., El-Domiaty N.A. and Wershana K., 1987. Effect of sodium chloride and calcium chloride on nitrite induced methemoglobinemia in Clarias lazera. Water Air Soil Pollut., 33, 57-63.

Holdich D.M., Harlioğlu M.M. and Firkins I., 1997. Salinity adaptations of crayfish in British waters with particular reference to Austropotamobius pallipes, Astacus leptodactylus and Pacifastacus leniusculus. Estuar. Coast. Shelf Sci., 44, 147-154.

Huertas M., Gisbert E., Rodriguez A., Williot P. and Castello-Orvay F., 2002. Acute exposure of Siberian sturgeon (Acipenser baeri, Brandt) yearlings to nitrite: median-lethal concentration (LCsub (50)) determination, haematological changes and nitrite accumulation in selected tissues. Aquat. Toxicol., 57, 4, 257-266.

Jeberg M.V. and Jensen F.B., 1994. Extracellular and intracellular ionic changes in crayfish Astacus astacus exposed to nitrite at two acclimation temperatures. Aquat. Toxicol., 29, 65-72.

Jensen F.B., 2003. Nitrite disrupts multiple physiological functions in aquatic animals. Comp. Biochem. Physiol. , A. Comp. Physiol., 135, 1, 9-24.

Kholodkevich S.V., Ivanov A.V., Kornienko E.L. and Kurakin A.S., 2007. Method of biological monitoring of the environment (variants) and a system for its performing, RF Patent (Invention) No. 2308720.

Kholodkevich S.V., Ivanov A.V., Kurakin A.S., Kornienko E.L. and Fedotov V.P., 2008. Real time biomonitoring of surface water toxicity level at water supply stations. Environ. Bioindic., 3, 23-34.

Kirschner L.B., 2004. The mechanism of sodium chloride uptake in hyperregulating animals. J. Exp. Biol., 207, 1439-1452.

Köksal G., 1988. Astacus leptodactylus in Europe. In: Holdich D.M. and Lowery R.S. (eds.), Freshwater Crayfish: Biology, Management and Exploitation, Chapman Hall, London, 365-400.

Kozák P., Máchová J. and Policar T., 2005. The effect of chloride content in water on the toxicity of sodium nitrite for spiny-cheek crayfish (Orconectes limosus Raf.). Bull. Fr. Pêche Piscic., 376-377, 705-714.

Love M.R., 1980. The chemical biology of fishes, Academic Press, New York.

Maetz J., 1971. Fish gills: mechanism of salt transfer in fresh water and sea water. Phil. Trans. Roy. Soc. Lond. B, 262, 209-249.

McMahon B.R., 1986. The adaptable crayfish. Freshwater Crayfish, 6, 59-74.

Morris S., 2001. Neuroendocrine regulation of osmoregulation and the evolution of air-breathing in Decapod crustaceans. J. Exp. Biol., 204, 979-989.

Newsom J.E. and Davis K.B., 1994. Osmotic responses of haemolymph in red swamp crayfish (Procambarus clarkii) and white river crayfish ( $P$. zonangulus) to changes in temperature and salinity. Aquaculture, 126, 373-381. 
Reiber C.L. and McMahon B.R., 1998. The effects of progressive hypoxia on the crustacean cardiovascular system: a comparison of the freshwater crayfish, (Procambarus clarkii), and the lobster (Homarus americanus). J. Comp. Physiol., B Biochem. Syst. Environ. Physiol., 168, 3, 168-176.

Reiber C.L., McMahon B.R. and Burggren W.W., 1997. Cardiovascular function in two macruran decapod crustaceans (Procambarus clarkii and Homarus americanus) during periods of inactivity, tail flexion and cardiorespiratory pauses. J. Exp. Biol., 200, 7, 1103-1113.

Rouse D.B. and Kartamulia I., 1992a. Use of sodium chloride to improve survival of the Australian crayfish Cherax tenuimanus. Prog. Fish Cult., 54, 2, 118-121.

Rouse D.B. and Kartamulia I., 1992b. Influence of salinity and temperature on molting and survival of the Australian freshwater crayfish (Cherax tenuimanus). Aquaculture, 105, 1, 47-52.

Russo R.C. and Thurston R.V., 1977. The acute toxicity of nitrite to fishes. In: Tubb R.A. (ed.), Recent Advances in Fish Toxicity, EPA-600/3-77-085, US Environmental protection Agency, Corvallis, 118-131.

Swash M. and Mason S., 1984. Hutchinson's Clinical Methods, 18th edition, Bailliere Tindall, London.

Tavares L.H.S. and Boyd C.E., 2003. Possible effect of sodium chloride treatment on quality of effluents from Alabama channel catfish ponds. J. World Aquacult. Soc., 34, 2, 217-222.

Williams E.M. and Eddy F.B., 1986. Chloride uptake in freshwater teleosts and its relationship to nitrite uptake and toxicity. J. Comp. Physiol. B, 156, 867-872. 